\title{
Influence of body weight and substrate granulometry on the reproduction of Limnodrilus hoffmeisteri (Oligochaeta: Naididae: Tubificinae)
}

\author{
Haroldo Lobo ${ }^{1,2} \&$ Roberto G. Alves ${ }^{1}$ \\ 1 Programa de Pós-Graduação em Ciências Biológicas - Comportamento e Biologia Animal, Departamento de Zoologia, \\ Instituto de Ciências Biológicas, Universidade Federal de Juiz de Fora. 33036-330 Juiz de Fora, MG, Brazil. \\ ${ }^{2}$ Corresponding author. E-mail: haroldo.Isn@gmail.com
}

\begin{abstract}
Limnodrilus hoffmeisteri Claparede, 1862 is a cosmopolitan Oligochaeta widely used as indicator of organic pollution in water bodies. Previous contributions have shown the effects of organic matter and temperature on the life history of the species, although very little is known about the factors that influence its reproduction. This study aimed 1) to test whether the larger weight of individuals results in an increase in the reproduction rate and 2) to test the influence of two granulometric fractions of sand on the reproduction and growth the species. In the first experiment, specimens of $L$. hoffmeisteri were separated in two groups with different average weights (small individuals $=6.63 \pm 1.28 \mathrm{mg}$; large individuals $=12.44 \pm 3.99 \mathrm{mg}$ ) and kept at $15 \pm 1{ }^{\circ} \mathrm{C}$ for 21 days. The results of this experiment showed that the number of cocoons was statistically similar between the groups, but the mean number of eggs per cocoon produced by large individuals $(2.78 \pm 0.35)$ was greater than that produced by small individuals $(7.45 \pm 2.50)$. In the second experiment, weekly observations were conducted for 25 weeks in two groups of 30 specimens: one kept in fine sand and the other in medium sand, at $25 \pm 1{ }^{\circ} \mathrm{C}$. The single significant difference was in the number of cocoons per adult per day $(0.37 \pm$ 0.22 and $0.23 \pm 0.24$, for fine and medium sand, respectively). Individuals reared in fine sand produced a greater number of descendants compared to those reared in medium sand in the same period of time.
\end{abstract}

KEY WORDS. Cocoon; growth rate; indetermined growth; tubificid; worms.

Species of limnic Oligochaeta are recognized as important food sources for various aquatic insects (LoDEN 1974) and fish (Kosiorek 1974, Riera et al. 1991, Gophen et al. 1998, RAHMAN et al. 2006). YAN \& LIANG (2004) found that Oligochaeta are a rich source of food, since $90 \%$ of their dry weight consists of protein and fat. Limnodrilus hoffmeisteri ClaPAREde, 1862 (Naididae) is a common and abundant aquatic oligochaeta in many parts of the world (KeNNEDy 1965), being widely used as an indicator of organically polluted environments (PaOletti \& Sambugar 1984, Verdonschot 1989, Finogenova 1996, Alves \& LucCa 2000, Alves et al. 2006, Dornfeld et al. 2006, Martins et al. 2008). The biology of this species has been widely studied (Kennedy 1966, Aston 1973, Juget et al. 1989, Nascimento \& Alves 2008), but the results of many studies (KenNedy 1965, Aston 1973, Fisher \& BeEton 1975, Reynoldson 1987, PAsteris et al. 1999, RABURU et al. 2002) differ, especially with respect to the growth rate and the number of cocoons and eggs found. These discrepancies come from the lack of standardized research methods (for example, differences in density, food quality, type of sediment), which makes it difficult to replicate the experiments and to compare their results (Fisher \& BeEton 1975, SobHana \& NAIR 1984).
Despite the elevated number of studies involving $L$. hoffmeisteri and organic pollution of aquatic environments, there is little data on the factors that influence this species' distribution, behavior, and reproduction, probably because taxonomic problems (Fisher \& BeEton 1975, SobHana \& NAir 1984, PASTERIS et al. 1999, RABURU et al. 2002). Aston (1973) noticed differences in the average number of eggs per cocoons in two different experiments with $L$. hoffmeisteri (one experiment on the effect of temperature, and another on the effect of dissolved oxygen, on egg production). He raised the hypothesis that this difference was influenced by the weight of the individuals used in the experiments, because they were different. Since then, there have been no attempts to corroborate Aston's hypothesis.

The substrate is essential to the survival and reproduction of oligochaeta and could influence the distribution of species. For instance, Aston \& MiLNer (1982) reported the importance of sediment to the survival, growth and reproduction of Tubificidae, since it facilitates dislocation and feeding, physically supporting the organisms during their respiratory movements. According to SAUTER \& GÜDE (1996), the size of the substrate grains influences the distribution of Oligochaeta species. Ecological 
studies have shown a positive relationship between the abundance of $L$. hoffmeisteri and the proportion of fine sediment (grain smaller than $0.21 \mathrm{~mm}$ ) (Sauter \& GÜDe 1996, Alves \& Strixino 2000). However, Moore (1979) highlighted the importance of organic matter to the distribution of these animals, since availability of organic matter increases the number of algae and bacteria - both food sources for Oligochaeta.

This study had two main objectives. The first was to test whether large individuals of $L$. hoffmeisteri produce more eggs and/or cocoons than small individuals. The second was to assess the influence of two granulometric fractions of sand on the reproduction and growth of $L$. hoffmeisteri under laboratory conditions.

\section{MATERIAL AND METHODS}

The specimens of $L$. hoffmeisteri used in the experiments were obtained from a culture maintained at the Laboratório de Invertebrados Bentônicos, Universidade Federal de Juiz de Fora (Juiz de Fora, MG, Brazil) under room temperature and controlled luminosity conditions. The sand used was collected from the Peixe River $\left(21^{\circ} 54^{\prime} 37^{\prime \prime} \mathrm{S}, 43^{\circ} 33^{\prime} 24^{\prime \prime} \mathrm{W}\right)$, located in the city of Juiz de Fora. It was previously inspected under a 40x stereomicroscope to remove invertebrates. The sand was separated into a medium fraction $(0.250-1.00 \mathrm{~mm})$ and a fine fraction (0.057-0.250 $\mathrm{mm}$ ) by sifting.

Relationship between body weight and egg-laying

A total of 50 adults in the reproductive stage (with visible clitelum and eggs in the ovisac) were chosen. They were weighted and separated into two groups: small individuals (25 individuals with $6.63 \pm 1.28 \mathrm{mg}$ of medium weight) and large individuals ( 25 individuals with $12.44 \pm 3.99 \mathrm{mg}$ of medium weight).

The individuals in each group were kept in five $250-\mathrm{mL}$ beakers (five individuals per beaker) containing $100 \mathrm{~mL}$ of fine sand and $100 \mathrm{~mL}$ of dechlorinated and well-aerated water. At the beginning of the experiment, $0.1 \mathrm{~g}$ (dry weight) of fish feed (Alcon BASIC ${ }^{\circledR}$ - MEP200 Complex - Tab. I) was added to each beaker as organic matter source. The treatments were maintained in Biological Oxygen Demand (B.O.D. - EletroLab ${ }^{\circledR}$ EL 101) incubators at $15 \pm 1^{\circ} \mathrm{C}$ for 21 days - similar conditions to those used by Aston (1973) -, with adjustments only of the water level.

At the end of 21 days, the sediment was washed in a 0.25 $\mathrm{mm}$ sifter and analyzed under a 40x stereomicroscope to count young, adults and cocoons. To count the eggs, sand grains attached to the cocoons were removed with a Stanley knife. We recorded final adult weight, number of cocoons and eggs, average number of cocoons per adult per day, average number of eggs per cocoon and average daily growth rate $\left(\mathrm{G}_{\mathrm{w}} \%\right.$, according to ReYNOLDSON 1987): $G_{w} \%=\left[\left(\ln _{2}-\ln _{1}\right) \times 100\right] \mathrm{x} \mathrm{t}^{-1}$, where: $\mathrm{W}_{1}=$ initial weight $(\mathrm{mg}) ; \mathrm{W}_{2}=$ final weight $(\mathrm{mg}) ; \mathrm{an} \mathrm{t}=$ time in days.
To compare the initial and final average weight of adults between the groups, the Mann-Whitney test at 5\% significance was used. The t-test (at 5\% significance) was used to compare the others variables (number of cocoons, number of eggs per cocoon, cocoons per adult per day, and $\mathrm{G}_{\mathrm{w}} \%$ ) between the treatments. All tests have an $\mathrm{n}$ of 10 (5 of each treatment), so that each beaker was a replica.

Table I. Composition of the fish food Alcon Basic ${ }^{\circledR}$ used as organic matter source in the experiments with Limnodrilus hoffmeisteri. Figures provided by the manufacturer (value per kilogram of the product).

\begin{tabular}{lc}
\hline \multicolumn{1}{c}{ Vitamin A } & $30,000 \mathrm{UI}$ \\
\hline Vitamin D3 & $5,000 \mathrm{UI}$ \\
Vitamin E & $83.3 \mathrm{mg}$ \\
Vitamin K3 & $8.3 \mathrm{mg}$ \\
Vitamin B1 & $6.7 \mathrm{mg}$ \\
Vitamin B2 & $25 \mathrm{mg}$ \\
Vitamin B6 & $6.7 \mathrm{mg}$ \\
Vitamin B12 & $33.3 \mathrm{mg}$ \\
Niacin & $116.7 \mathrm{mg}$ \\
Calcium Pantothenate & $50 \mathrm{mg}$ \\
Biotin & $0.3 \mathrm{mg}$ \\
Folic Acid & $2.5 \mathrm{mg}$ \\
Hill & $520 \mathrm{mg}$ \\
Iron & $83.3 \mathrm{mg}$ \\
Cupper & $8.3 \mathrm{mg}$ \\
Zinc & $83.3 \mathrm{mg}$ \\
Manganese & $66.7 \mathrm{mg}$ \\
Selenium & $0.2 \mathrm{mg}$ \\
lodine & $1.7 \mathrm{mg}$ \\
Methionine & $833.3 \mathrm{mg}$ \\
Stabilized Vitamin C & $250 \mathrm{mg}$ \\
\hline
\end{tabular}

\section{Influence of grain size on the reproduction}

We assessed the effect of grain size in three steps: 1) cocoon production; 2) hatching; and 3) growth and reproduction. This assessment was conducted in 250 -mL beakers, which contained $100 \mathrm{~mL}$ of substrate (fine or medium sand), $100 \mathrm{~mL}$ of water (dechlorinated and aerated) and $0.1 \mathrm{~g}$ of fish food (Alcon BASIC $^{\circledR}$ - MEP200 Complex) as a source of organic matter.

In the first step, specimens were kept in 12 beakers (six with fine sand and six with medium sand), each containing five mature specimens, to allow them to produce the cocoons. The beakers were kept in incubators at $25 \pm 1^{\circ} \mathrm{C}$. Every other day, for 20 days, the substrate of each beaker was washed in a 
$0.25-\mathrm{mm}$ sifter and analyzed under a stereomicroscope to collect and count the cocoons.

In the second step, we used a 3-mL Pasteur pipette to remove cocoons from the sifter and transferred them to 100$\mathrm{mL}$ beakers, containing $25 \mathrm{~mL}$ of substrate (fine or medium sand, according to the substrate in which they were collected) and $25 \mathrm{~mL}$ of dechlorinated and aerated water. All cocoons collected on the same day for each substrate were put in the same beaker (one with fine sand and another one with medium sand). The beakers containing the cocoons were kept in incubators at $25 \pm 0.1^{\circ} \mathrm{C}$ and analyzed under a stereomicroscope every other day (during a 20-day period) to observe and count eclosions, allowing the observers to record the time between laying the cocoon and its eclosion.

The third step began with the selection of 30 young individuals for each type of substrate among the new hatchings, to observe growth and sexual maturation. Individuals were selected based on the presence of normal movement and absence of body deformations. For each substrate, six 250-mL beakers, containing $100 \mathrm{~mL}$ of sand, $100 \mathrm{~mL}$ of water and five individuals each, were analyzed weekly during 25 weeks (175 days). The weights of individuals' and the number of eggs and cocoons were recorded. In order to do this, the substrate was washed in 0.25 $\mathrm{mm}$ sifters and analyzed under a stereomicroscope. We started weighing the individuals a week after their eclosion, because they were very small at the time of hatching, and the process could hurt them. To avoid stress, before washing the substrate, we removed the organisms and put them in a Petri dish containing only dechlorinated water. After having collected the cocoons we put the organisms back in the beakers filled with new sand and water, and with $0.1 \mathrm{~g}$ of fish food.

For each treatment, average daily growth rate $\left(\mathrm{G}_{\mathrm{w}} \%\right)$, time of sexual maturation, number of cocoons per adult per day and number of eggs per cocoon were determined. The test of proportion (z-test) with an $\mathrm{n}$ of 2 was used to compare the proportion of eclosion in each interval of time between the treatments. The $t$-test was used to compare the average time of sexual maturation, mean individual weight, average number of eggs per cocoon and average number of cocoons per adult weekly between the two types of sand. For all tests, a 5\% of significance was adopted, with $\mathrm{n}=12$. The weights of individuals were transformed in natural logarithm $[\ln ($ weight +1$)]$ to normalize their distribution (the Shapiro-Wilks Normality Test was used with $5 \%$ of significance).

\section{RESULTS}

\section{Relationship between body weight and egg-laying}

A total of $93.3 \%$ of the small and $100 \%$ of the large individuals survived. The initial weights of small and large individuals were $6.63 \pm 1.28 \mathrm{mg}$ and $12.44 \pm 3.99 \mathrm{mg}$, respectively $(\mathrm{U}=538.00 ; \mathrm{n}=10 ; \mathrm{p}<0.001)$ and, after 21 days, the final weights were $8.01 \pm 1.60 \mathrm{mg}$ for small and $15.89 \pm 5.97 \mathrm{mg}$ for large individuals $(\mathrm{U}=540.00, \mathrm{n}=10, \mathrm{p}<0.001)$. There was no significant difference between the average daily growth rates $\left(\mathrm{G}_{\mathrm{w}} \%\right)$ of small and large individuals $(0.90 \pm 0.48 \%$ and $1.17 \pm$ $1.19 \%$, respectively; $\mathrm{t}=0.598, \mathrm{n}=10, \mathrm{p}=0.574$ ).

There was no significant difference between the number of cocoons for the two classes of individual size $(t=2.102, n=$ 10, p = 0.069; Fig. 1) and neither between the number of cocoons per adult per day $(0.109 \pm 0.037$ and $0.160 \pm 0.041$, small and large individuals, respectively; $\mathrm{t}=2.102, \mathrm{n}=10, \mathrm{p}=0.069$ ). However, the number of eggs per cocoon laid by large individuals $(7.45 \pm 2.50)$ was significantly greater than that by small ones $(2.78 \pm 0.35)(\mathrm{t}=4.132, \mathrm{n}=10, \mathrm{p}=0.013)$.

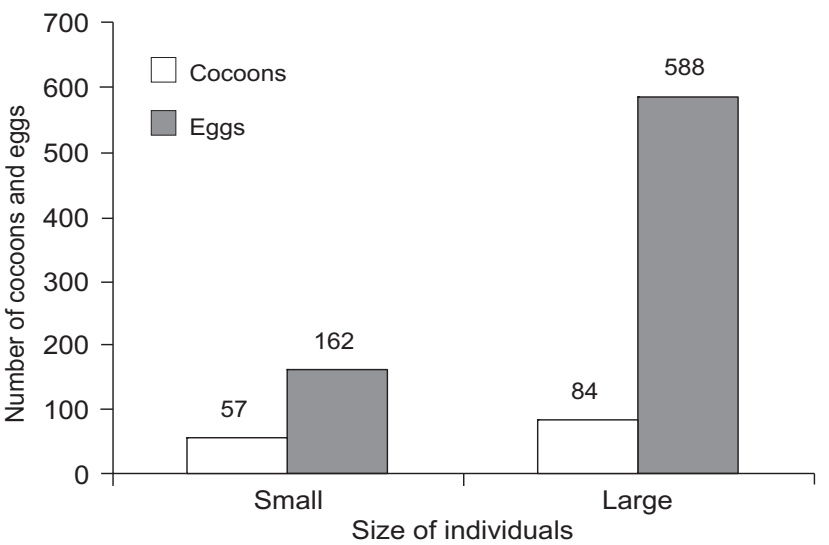

Figure 1. Number of cocoons and number of eggs laid by Limnodriulus hoffmeisteri by small (initial average weight $6.63 \pm$ $1.28 \mathrm{mg}$ ) and large individuals (initial average weight $12.44 \pm$ $3.99 \mathrm{mg})$, at $15 \pm 1^{\circ} \mathrm{C}$.

\section{Influence of grain size on the reproduction}

A total of 115 cocoons from fine sand and 101 from medium sand were collected at the first step. The time between laying the cocoon and its eclosion, observed at the second step, is shown in figure 2. In fine sand, $84.83 \%$ of the young hatched between 8 and $12 \mathrm{~d}$. Virtually the same rate was observed for medium sand, $83.67 \%$ hatched in the same period $(z=0.321$, $\mathrm{n}=2, \mathrm{p}=0.748$ ).

The curves of growth (Fig. 3) show almost a constant weight gain during the 25 weeks of observation. Comparing the two curves, it is possible to observe that the individuals maintained in medium sand grew less than individuals maintained in fine sand. This difference became more evident after the 18th week. Despite this, the average daily growth rates $\left(G_{w} \%\right)$ for the two treatments at the end of the 25 weeks did not differ significantly (Tab. II).

The time of sexual maturation (laying of the first cocoon) varied between 3 and 10 weeks of life (average $7.17 \pm 2.93$ ) for the organisms kept in fine sand, and 6 to 11 weeks (average 


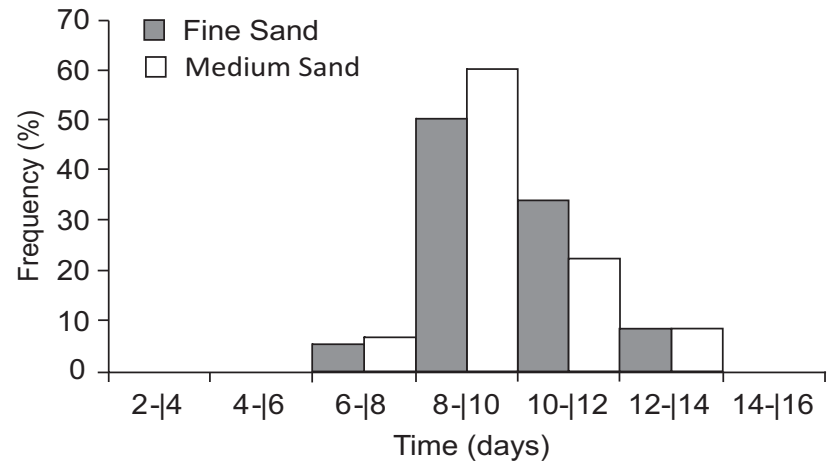

Figure 2. Time between laying the cocoon and eclosion of Limnodrilus hoffmeisteri cultivated in medium sand (0.250-1.000 $\mathrm{mm})$ and fine sand $(0.057-0.250 \mathrm{~mm})$ at $25 \pm 1^{\circ} \mathrm{C}$.

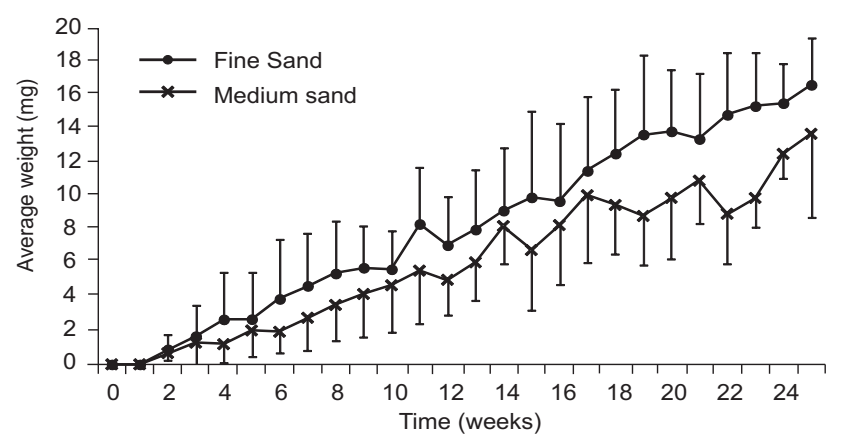

Figure 3. Average weight ( \pm standard deviation) of Limnodrilus hoffmeisteri cultivated in fine sand $(0.057-0.250 \mathrm{~mm})$ and medium sand $(0.250-1.000 \mathrm{~mm})$ at $25 \pm 1{ }^{\circ} \mathrm{C}$.

$9.00 \pm 2.00)$ for those kept in medium sand $(\mathrm{t}=-1.228, \mathrm{n}=12$, $\mathrm{p}=0.251$ ). The average number of cocoons per adult per week was slightly higher in the fine sand treatment in almost all weeks (Fig. 4). Therefore, in the end of the 25 weeks, the avarege number of cocoons per adult in fine sand was greater than in medium sand (Tab. II). By contrast, the number of eggs per cocoons was similar in all weeks (Fig. 5) and at the end of the 25 weeks (Tab. II).

\section{DISCUSSION}

The cocoons of $L$. hoffmeisteri are covered with fine sediment particles that decrease their detection in the substrate (Aston 1973, LAzim et al. 1989), a fact that was also observed in this study. This characteristic is likely to provide more protection against organisms that can harm embryo development. Asтоn (1973), in two different experiments, observed an average of approximately 5 and 1.35 eggs per cocoon when he studied $L$. hoffmeisteri, with average weights of 10.5 and $3.5 \mathrm{mg}$, respectively. His results, combined with the results of the present study, show a positive correlation between the weight of individuals and the number of eggs per cocoon. Paris \& Pitelka (1962) found a positive relationship between the size of the female of Armadillidium vulgare Latreille, 1804, a terrestrial isopod, and the number of juveniles produced. VReys \& Michiels (1995) and Ilano et al. (2004) observed a positive correlation between the size of the genitor and the number of eggs/cocoons produced by the gastropod Buccinum isaotakii (Kira, 1959) and the planaria Dugesia gonocephala (Girard, 1850). These studies confirm the positive relationship between body mass and reproduction for some invertebrates.

An interesting observation is that heavier $L$. hoffmeisteri individuals laid more eggs per cocoon, while the number of cocoons from lighter and heavier invidicuals was statistically similar (present study). By contrast, an increase in temperature led to an increase in the number of cocoons of this species, while the number of eggs per cocoon was maintained (NASCIMENTO \& ALVES 2009). Higher temperatures accelerate the metabolism of organisms and cause an increase in the number of reproductive events (Howe 1967). In Oligochaeta this can be represented by the number of cocoons produced. Moreover, an increase in body weight leads to more fertility, which implies a greater number of eggs per individual (VReys \& MichieLs 1995). Individuals with larger body mass can invest more energy in reproduction, so they have more reproductive success compared to smaller conspecifics (VReys \& Michiels 1995).

In the preset study, a positive growth rate was practically constant throughout the experiment, even after the specimens reached sexual maturity and laid their cocoons. MARCHESE \& BRINKHURST (1996) observed a negative growth rate (Gw\%) and a posterior stabilization of the weight of individuals of Branchiura

Table II. Average number of eggs per cocoon ( \pm standard deviation [SD]) and of cocoons per adult per day ( \pm SD), and average rate of daily growth (Gw\%) ( \pm SD), observed for Limnodrilus hoffmeisteri cultivated in fine sand (0.057-0.250 mm) and medium sand (0.250$1.000 \mathrm{~mm})$ at $25 \pm 1^{\circ} \mathrm{C}$ during 175 days.

\begin{tabular}{|c|c|c|c|c|}
\hline & \multirow{2}{*}{$\begin{array}{c}\text { Fine sand } \\
\text { Average } \pm \text { SD }\end{array}$} & \multirow{2}{*}{$\frac{\text { Medium sand }}{\text { Average } \pm S D}$} & \multicolumn{2}{|c|}{ t-test } \\
\hline & & & $\mathrm{t}$ & $p$-value \\
\hline Eggs $\cdot$ cocoon $^{-1}$ & $3.12 \pm 1.03$ & $3.06 \pm 1.21$ & 0.317 & 0.751 \\
\hline Cocoons.adult.day ${ }^{-1}$ & $0.37 \pm 0.22$ & $0.23 \pm 0.24$ & 3.414 & $<0.001$ \\
\hline Gw\% & $2.14 \pm 0.75$ & $2.04 \pm 0.42$ & 0.291 & 0.778 \\
\hline
\end{tabular}



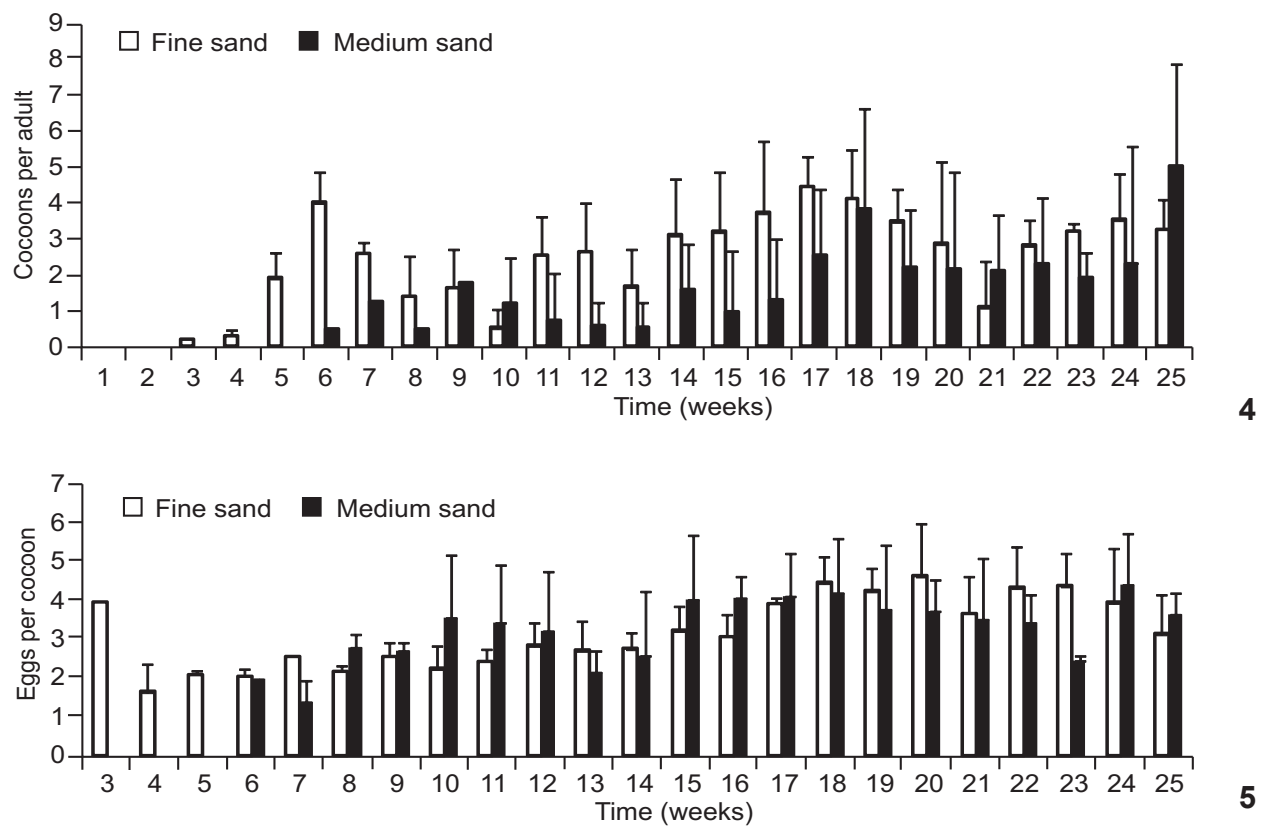

Figures 4-5. (4) Average number of cocoons per adult per week and (5) Weekly average of eggs per cocoon of Limnodrilus hoffmeisteri cultivated in fine sand $(0.057-0.250 \mathrm{~mm})$ and medium sand $(0.250-1.000 \mathrm{~mm})$ at $25 \pm 1^{\circ} \mathrm{C}$.

sowerbyi Beddard, 1892 (Naididae: Tubificinae) after they laid their first cocoon. SEBENS (1987) emphasizes that some invertebrates, including Oligochaeta, can exhibit undetermined growth, with no asymptote in the growth curve. This growth pattern seems to be present in L. hoffmeisteri, because even in the reproduction phase the organisms continue to grow constantly.

According to the results of NAscimento \& Alves (2009), the time of embryonic development following eclosion for $L$. hoffmeisteri was less than 21 days at $25^{\circ} \mathrm{C}$. This agrees with our findings here, which showed that more than $80 \%$ of the young specimens hatched within 8 to 12 days after the cocoon was laid. This period is shorter than that observed for $B$. sowerbyi (14 to 16 days) under similar temperature conditions (Nascimento \& Alves 2008, Lobo \& Alves 2011).

Aston (1973) observed that L. hoffmeisteri is capable of developing from an embryo to a mature individual in less than five weeks. The development period obtained here was longer (seven weeks on average) than observed by that author. This may have been a result of the stress caused by weekly handling. According to MARCHESE \& BRINKHURST (1996), development is slower in individuals of $B$. sowerbyi handled on a weekly basis than in individuals handled every two weeks. For L. hoffmeisteri, weekly observations are necessary, since after two weeks there would be a large number of young specimens hatching, making it difficult to assess the number of eggs per cocoon.

In the present study, a significant difference between the two granulometric fractions tested was not observed for most parameters analyzed. The most important difference observed was the average number of cocoons per adult per day, which was greater in fine sand treatment. This shows that individuals living in this kind of substrate are more fit, since they can breed a greater number of descendants in a longer period of time. This is a likely explanation for the positive correlation between the abundance of $L$. hoffmeisteri and the fine fraction of sediment (< $0.210 \mathrm{~mm}$ ) from Diogo Lagoon (Luiz Antônio, SP, Brazil) reported by Alves \& STRIXINo (2000). Additionally, it should account for the observation of largest number of cocoons reported by Aston \& Milner (1982) in their experiment mixing fine sand (0.072$0.250 \mathrm{~mm})$ and medium sand $(0.250-1.000 \mathrm{~mm})$ in activated sewage (product from sewage treatment, containing $78 \%$ organic matter), compared to other tested grain size fractions (pure activated sewage, coarse sand, clay, and mud).

We conclude that the hypothesis raised by AsTon (1973), that large individuals of $L$. hoffmeisteri produce a larger amount of eggs, is accepted, since the body weight positively correlated with the number of eggs produced. Additionally, we conclude that the grain size influences the reproduction of the species, with individuals reared in fine sediment producing more eggs per cocoon than those reared in medium sediment.

\section{ACKNOWLEDGMENTS}

We would like to thank the Fundação de Amparo à Pesquisa do Estado de Minas Gerais (FAPEMIG) for the research grant given to the first author, and all the reviewers for the suggestions that increase the quality of this paper. 


\section{LITERATURE CITED}

Alves, R.G. \& J.V. Lucca. 2000. Oligochaeta como indicador de poluição orgânica em dois córregos pertencentes a Bacia do Ribeirão do Ouro - Araraquara (São Paulo, Brasil). Brazilian Journal of Ecology 2: 112-117.

Alves, R.G. \& G. Strixino. 2000. Distribuição especial de Oligochaeta em uma lagoa marginal do rio Mogi-Guaçu, São Paulo Brasil [Spatial distribution of Oligochaeta in a marginal lake of the Mogi-Guaçu River, São Paulo, Brazil]. Iheringia, Série Zoologia, 88: 173-180.

Alves, R.G.; M.R. Marchese \& S.C. Escarpinati. 2006. Oligochaeta (Annelida, Clitellata) in lotic environments in the State of São Paulo, Brazil. Iheringia, Série Zoologia, 96: 431-435.

Aston, R.J. 1973. Field and experimental studies on the effects of a power station effluent on Tubificidae (Oligochaeta, Annelida). Hydrobiologia 42: 225-242. doi: 10.1007/BF00014116.

Aston, R.J. \& A.G.P. Milner. 1982. Conditions required for the culture of Branchiura sowerbyi (Oligochaeta: Tubificidae) in activated sludge. Aquaculture 26: 155-166.

Calow, P. 1979. The costs of reproduction - a physiological approach. Biological Reviews 54: 23-40.

Dorfeld, C.B.; R.G. Alves; M.A. Leite \& E.L.G Espíndola. 2006. Oligochaeta in eutrophic reservoir: the case of Salto Grande reservoir and their main affluent (Americana, São Paulo, Brazil). Acta Limnologica Brasiliensia 18 (2): 189-197.

Finogenova, N.P. 1996. Oligochaete communities at the mouth of the Neva and their relationship to anthropogenic impact. Hydrobiologia 334: 185-191. doi: 10.1007/BF00017368.

Fisher, J.A. \& A.M. BeEton. 1975. The effect of dissolved oxygen on the burrowing behavior of Limnodrilus hoffmeisteri (Oligochaeta). Hydrobiologia 47: 273-290. doi: 10.1007/BF00039060.

Gophen, M; Y. Yehuda; A. Malinkov \& G. Degani. 1998. Food composition of the fish community in Lake Agmon. Hydrobiolgia 380: 49-57. doi: 10.1023/A:1003225210226.

HowE, R.W. 1967. Temperature effects on embryonic development in insects. Annual Review of Entomology 12: 15-42.

Ilano, A.S.; K. Fujinaga \& S. NaKao. 2004. Mating, development and effects of female size on offspring number and size in the neogastropod Buccinum isaotakii (Kira, 1959). Journal of Molluscan Studies 70: 277-282.

Juget, J.; V. Goubier \& D. BARThÉLÉMy. 1989. Intrinsic and extrinsic variables controlling the productivity of asexual populations of Nais spp. (Naididae, Oligochaeta). Hydrobiologia 180: 177-184. doi: 10.1007/BF00027550.

Kennedy, C.R. 1965. The distribution and habitat of Limnodrilus hoffmeisteri (Oligochaeta: Tubificidae). Oikos 16: 26-38.

Kennedy, C.R. 1966. The life history of Limnodrilus hoffmeisteri Clap. (Oligochaeta: Tubificidae) and its adaptive significance. Oikos 17: 158-168.

Kosiorek, D. 1974. Development cycle of Tubifex tubifex Müll. In experimental culture. Polskie Archiwum Hydrobiologii 24: 411-422.
LaZim, M.N.; M.A. Learner \& S. CoOper. 1989. The importance of worm identify and life history in determining the vertical distribution of tubificids (Oligochaeta) in a riverine mud. Hydrobiologia 178: 81-92. doi: 10.1007/BF00006115.

Loвo, H. \& R.G. Alves. 2011. Reproductive cycle of Branchiura sowerbyi (Oligochaeta: Naididae: Tubificinae) cultivated under laboratory conditions. Zoologia 28 (4): 427-431. doi: 10.1590/S1984-46702011000400003.

Loden, M.S. 1974. Predation by chironomid (Diptera) larvae on oligochaetes. Limnology and Oceanography 19: 156-159.

Marchese, M.R. \& R.O. Brinkhurst. 1996. A comparison of two tubificid oligochaete species as candidates for sublethal bioassay tests relevant to subtropical an tropical regions. Hydrobiologia 334: 163-168. doi: 10.1007/BF00017366.

Martins, R.T.; N.N.C. Stephan \& R.G. Alves. 2008. Tubificidae (Annelida: Oligochaeta) as an indicator of water quality in an urban stream in southeast Brazil. Acta Limnologica Brasiliensia 20 (3): 221-226.

Moore, J.W. 1979. Influence of food availability and other factors on the composition, structure and density on a subartic population of benthic invertebrates. Hydrobiologia 62: 215-223. doi: 10.1007/BF00043538.

Nascimento, H.L.S. \& R.G. Alves. 2008. Cocoon production and hatching rates of Branchiura sowerbyi Beddard (Oligochaeta: Tubificidae). Revista Brasileira de Zoologia 25 (1): 16-19. doi: 10.1590/S0101-81752008000100003.

Nascimento, H.L.S. \& R.G. Alves. 2009. The effect of temperature on the reproduction of Limnodrilus hoffmeisteri (Oligochaeta, Tubificidae). Zoologia 26 (1): 191-193. doi: 10.1590/S198446702009000100026.

Paoletti, A. \& B. Sambugar.1984. Oligochaeta of the middle Po River (Italy): principal component analysis of the benthic data. Hydrobiologia 115: 145-152. doi: 10.1007/BF00027909.

Paris, O.H. \& F.A. PitelKa. 1962. Population characteristics of the terrestrial isopod Armadillidium vulgare in California Grassland. Ecology 43: 229-248.

Pasteris, A.; M. Vecchi \& G. Bonomi. 1999. A comparison among different population models for Limnodrilus hoffmeisteri Claparèd (Oligochaeta, Tubificidae). Hydrobiologia 406: 183-189. doi: 10.1023/A:1003748520202.

Raburu, P.; K.M. Mavuti; D.M. Harper \& F.L.Clark. 2002. Population structure and secondary productivity of Limnodrilus hoffmeisteri (Claparede) and Branchiura sowerbyi Beddard in the profundal zone of Lake Naivasha. Hydrobiologia 488: 153-161. doi: 10.1023/A:1023382631822.

Rahman, M.M.; M.C.J. Verdegem; L.A.J. NagelKerke; M.A. Wahab; A. Milstein \& J.A.J. Verreth. 2006. Growth, production and food preference of rohu Labeo rohita (H.) in monoculture and in polyculture with common carp Cyprinus carpio (L.) under fed and non-fed ponds. Aquaculture 257: 359-372. doi: 10.1016/j.aquaculture.2006.03.020.

REynoldson, T.B. 1987. The role of environmental factors in the ecology of tubificid oligochaetes - an experimental study. 
Holartic Ecology 10: 241-248.

Riera, P.; J. Juget \& F. Martinet. 1991. Predator-prey interactions: effects of carp predation on Tubificid dynamics and carp production in experimental fishpond. Hydrobiologia 226: 129-136. doi: 10.1007/BF00006855.

SAUter, G. \& H. GÜde. 1996. Influence of grain size on the distribution of tubificid oligocahete species. Hydrobiologia 334: 97-101. doi: 10.1007/BF00017358.

Sebens, K.P. 1987. The ecology of indeterminate growth in animals. Annual Review of Ecology and Systematics 18: 371-407. doi: 0066-4162/87/1120-0371.

Sobhana, S. \& N.B. Nair. 1984. Observations on the breeding frequency of Branchiura sowerbyi Beddard and Limnodrilus hoffmeisteri Clapared (Annelida: Oligochaeta: Tubificidae). Comparative Physiology and Ecology 9: 302-305.

Verdonschot, P.F.M. 1989. The role of oligochaetes in the management of waters. Hydrobiologia 180: 213-227. doi: 10.1007/BF00027554.

VReys, C. \& N. Michiels. 1995. The influence of body size on immediate reproductive success in Dugesia gonocephala (Tricladida, Paludicola). Hydrobiologia 305: 113-117. doi: 10.1007/BF00036371.

YAN, Y. \& Y. LIANG. 2004. Energy flow in Branchiura sowerbyi (Oligochaeta: tubificidae) in a shallow macrophyte-dominated lake, Biandantang Lake. Chinese Journal of Oceanography Limnolology 22: 403-407.

Submitted: 08.I.2011; Accepted: 06.VI.2011

Editorial responsibility: Adriano S. Melo 